\title{
Locomotor Sensitization to Ethanol Impairs NMDA Receptor-Dependent Synaptic Plasticity in the Nucleus Accumbens and Increases Ethanol Self-Administration
}

\author{
Karina Possa Abrahao, ${ }^{1,2}$ Olusegun J. Ariwodola, ${ }^{1}$ Tracy R. Butler, ${ }^{1}$ Andrew R. Rau, ${ }^{1}$ Mary Jane Skelly, ${ }^{1}$ Eugenia Carter, ${ }^{1}$ \\ Nancy P. Alexander, ${ }^{1}$ Brian A. McCool, ${ }^{1}$ Maria Lucia 0. Souza-Formigoni, ${ }^{3}$ and Jeffrey L. Weiner ${ }^{1}$ \\ ${ }^{1}$ Department of Physiology and Pharmacology, Wake Forest School of Medicine, Winston-Salem, North Carolina 27157, ${ }^{2}$ Departamento de Farmacologia, \\ Instituto de Ciências Biomédicas, Universidade de São Paulo, São Paulo, SP, 05508-900 Brazil, and ${ }^{3}$ Departamento de Psicobiologia, Escola Paulista de \\ Medicina, Universidade Federal de São Paulo, São Paulo, SP, CEP 04023-062, Brazil
}

Although alcoholism is a worldwide problem resulting in millions of deaths, only a small percentage of alcohol users become addicted. The specific neural substrates responsible for individual differences in vulnerability to alcohol addiction are not known. In this study, we used rodent models to study behavioral and synaptic correlates related to individual differences in the development of ethanol locomotor sensitization, a form of drug-dependent behavioral plasticity associated with addiction vulnerability. Male Swiss Webster mice were treated daily with saline or $1.8 \mathrm{~g} / \mathrm{kg}$ ethanol for $21 \mathrm{~d}$. Locomotor activity tests were performed once a week for 15 min immediately after saline or ethanol injections. After at least $11 \mathrm{~d}$ of withdrawal, cohorts of saline- or ethanol-treated mice were used to characterize the relationships between locomotor sensitization, ethanol drinking, and glutamatergic synaptic transmission in the nucleus accumbens. Ethanol-treated mice that expressed locomotor sensitization to ethanol drank significantly more ethanol than saline-treated subjects and ethanol-treated animals resilient to this form of behavioral plasticity. Moreover, ethanol-sensitized mice also had reduced accumbal NMDA receptor function and expression, as well as deficits in NMDA receptor-dependent long-term depression in the nucleus accumbens core after a protracted withdrawal. These findings suggest that disruption of accumbal core NMDA receptor-dependent plasticity may represent a synaptic correlate associated with ethanol-induced locomotor sensitization and increased propensity to consume ethanol.

\section{Introduction}

Drug addiction is a pathology related to compulsive drug seeking and ingestion despite negative consequences (Robinson and Berridge, 1993; Vanderschuren and Kalivas, 2000; Hyman et al., 2006). There is a growing consensus that addiction is a disorder of neuroplasticity promoted by a strong association between drugs of abuse and their associated stimuli. Addicts have difficulty changing their focus, perseverate on their abused drugs, and struggle to learn new associations. Indeed, drugs of abuse disrupt both long-term depression (LTD) and long-term potentiation of synaptic transmission in the mesolimbic system (Luscher and Malenka, 2011; Mameli and Luscher, 2011; McCool, 2011).

\footnotetext{
Received Nov. 21, 2011; revised Jan. 22, 2013; accepted Jan. 24, 2013.

Author contributions: K.P.A., B.A.M., and J.L.W. designed research; K.P.A., O.J.A., T.R.B., A.R.R., M.J.S., E.C., and N.P.A. performed research; K.P.A., T.R.B., A.R.R., M.J.S., E.C., N.P.A., B.A.M., and J.L.W. analyzed data; K.P.A., M.L.O.S.-F., and J.L.W. wrote the paper.

Funding support was from the National Institutes of Health (Grants AA 21099, AA 17531, AA 10422, and AA 14445), Coordenadoria de Aperfeiçoamento de Pessoal de Nível Superior (CAPES; Grant 0321-10-9), Fundação de Amparo à Pesquisa do Estado de São Paulo (FAPESP; Grant 2008/01819-5), and Associação Fundo de Incentivo à Pesquisa (AFIP).

The authors declare no competing financial interests.

Correspondence should be addressed to Jeffrey L. Weiner, Department of Physiology and Pharmacology, Wake Forest School of Medicine, Medical Center Boulevard, Winston-Salem, NC 27157-1083. E-mail: jweiner@ wakehealth.edu.

DOI:10.1523/JNEUROSCI.5839-11.2013

Copyright $\odot 2013$ the authors $\quad 0270-6474 / 13 / 334834-09 \$ 15.00 / 0$
}

Exposure to psychostimulants can disrupt NMDA receptordependent LTD in the nucleus accumbens (NAc; Thomas et al., 2001; Martin et al., 2006; Mao et al., 2009; Kasanetz et al., 2010). Evidence suggests that disruption of accumbal LTD may represent a synaptic correlate of addiction vulnerability, because it persists in rats that develop behavioral hallmarks of cocaine addiction but not in rats resilient to this "addictive" phenotype (Kasanetz et al., 2010). Drugs of abuse induce addiction in only a subset of users. Addiction is therefore not simply a product of the neurobiological effects of drugs, but rather the consequence of drug exposure interacting with genetic and environmental backgrounds (Piazza and Le Moal, 1996; Deroche-Gamonet et al., 2004; Swendsen and Le Moal, 2011).

Ethanol is one of the most widely used drugs in the world and its global burden of disease is immense, with an estimated 3-4\% of deaths attributed to alcohol consumption (Rehm et al., 2009; Spanagel et al., 2010). Despite these statistics, little is known about the neurobiological mechanisms contributing to individual differences in susceptibility to alcoholism. Marked heterogeneity in behavioral responsivity to ethanol has been demonstrated in animals (Bell et al., 2006; Fidler et al., 2011; Melon and Boehm, 2011). Locomotor sensitization, a drugdependent behavioral adaptation defined as a progressive increase in psychomotor stimulant response, has been suggested as a behavioral marker for alcohol preference and/or abuse liability 
in animals (Grahame et al., 2000; Lessov et al., 2001) and humans (Newlin and Thomson, 1999). Our previous studies have identified individual differences in the development of ethanol locomotor sensitization in outbred Swiss Webster mice: whereas a subgroup of ethanol-treated mice showed robust sensitization, others receiving identical treatment failed to show this behavioral adaptation (Souza-Formigoni et al., 1999; Abrahao et al., 2011). Because variations in sensitization may reflect individual differences in addiction vulnerability, we sought to identify behavioral and neurobiological correlates associated with vulnerability and resilience to ethanol sensitization. Previous data have indicated that ethanol-sensitized and ethanol-nonsensitized mice may have differences in NMDA receptor activity (Abrahao and SouzaFormigoni, 2012). Interestingly, as observed with psychostimulants, chronic ethanol exposure has also been shown to disrupt NMDA receptor-mediated LTD in the NAc (Jeanes et al., 2011). However, whether this addiction-associated form of synaptic plasticity may contribute to individual differences in vulnerability to alcoholism is not known. We therefore integrated behavioral, electrophysiological, and biochemical techniques to test the hypothesis that enduring alterations in NAc glutamatergic receptor function and NMDA receptor-dependent plasticity may be associated with individual differences in ethanol-mediated locomotor sensitization and, consequently, addiction vulnerability.

\section{Materials and Methods}

Locomotor response to ethanol. Fifty-five- to 62-d-old adult male Swiss Webster mice (Charles River Laboratories), an outbred strain, were group housed (4-5 mice per cage) in a temperature-controlled colony room $\left(22 \pm 1^{\circ} \mathrm{C}\right)$ with lights on between 7:00 A.M. and 7:00 P.M. (except where indicated) with food and water given ad libitum. All animal procedures were performed in accordance with the National Institutes of Health Guide for the Care and Use of Laboratory Animals and were approved by the institutional animal care and use committee. Locomotor activity tests were performed using Tru Scan activity systems (Coulbourn Instruments). An ethanol dose-response curve was first conducted to select an appropriate ethanol dose for the locomotor sensitization experiments. On the first day, a drug-free locomotor activity test session (15 $\min$ ) was performed to assess baseline horizontal locomotor activity. One day later, mice were given intraperitoneal injections of either saline $(0.9 \% \mathrm{w} / \mathrm{v} \mathrm{NaCl})$ or ethanol $(1.5,1.8,2.0,2.2,2.5$, or $2.8 \mathrm{~g} / \mathrm{kg}, 15 \% \mathrm{w} / \mathrm{v})$ using a between-subject design, and immediately placed in the locomotor activity arena where horizontal locomotor activity was monitored for $15 \mathrm{~min}$. There was an overall effect of ethanol treatment $(p<0.05)$ and post hoc analyses revealed a significant stimulant effect of 2.2 and $2.5 \mathrm{~g} / \mathrm{kg}$ ethanol relative to saline administration (one-way ANOVA: $F_{(6,53)}=$ $6.43, p<0.001$, data not shown). Chronic treatments and the classification of locomotor sensitization were conducted as described previously (Souza-Formigoni et al., 1999; Abrahao et al., 2009). To assess baseline horizontal locomotor activity, all animals were initially tested in one drug-free session (15 min). One day later, mice received daily treatment (21 d) of either saline or $1.8 \mathrm{~g} / \mathrm{kg}$ ethanol intraperitoneally (this dose was chosen from the ethanol dose-response curve because it was on the ascending part of the inverted $\mathrm{U}$ locomotor activity response curve typically observed after ethanol treatment and it was below the peak stimulant effect). Locomotor activity was recorded for 15 min immediately after injections on treatment days $1,7,14$, and 21 . All procedures were performed between 10:00 A.M. and 04:00 P.M. Based on their locomotor response on day 21, ethanol-treated mice were sorted and classified as "sensitized" mice (activity scores in the upper 33\% of the distribution) and "nonsensitized" mice (activity scores in the lower 33\% of the distribution). Subjects with a locomotor response in the intermediate range were not used in further studies. Because electrophysiological studies could only be conducted on one animal per day, mice were treated and classified in cohorts of 24 animals: 18 ethanol-treated mice (which resulted in six sensitized, six nonsensitized, and six intermediate mice) and six saline-treated mice. This procedure was repeated a total of four times. For the following measures, the experimenter was blinded to the treatment group of the subjects.

EtOH self-administration. A modified "Drinking in the Dark" protocol (Finn et al., 2007) was used to assess voluntary ethanol intake in salineand ethanol-treated mice. Three days after the end of the chronic treatment regimen, mice were individually housed and the light-dark cycle was shifted $5 \mathrm{~h}$ (lights on between 2:00 A.M. and 2:00 P.M.). Eight days later, animals were given forced access to a $10 \%$ ethanol (v/v) solution for 3 consecutive days (i.e., $10 \%$ ethanol as the only solution available). Nine hours after the $3 \mathrm{~d}$ forced exposure to ethanol, voluntary ethanol intake and preference were assessed using a limited access two-bottle choice procedure (water available ad libitum, ethanol available for $2 \mathrm{~h}$ a day, $3 \mathrm{~h}$ into the dark cycle). Mice had access to water and $10 \%$ ethanol $(\mathrm{v} / \mathrm{v})$ during the first week. Then, after $2 \mathrm{~d}$ of withdrawal, mice had access to water and $20 \%$ ethanol (v/v) during the second week. There were no statistically significant group differences in ethanol intake during the $3 \mathrm{~d}$ of forced ethanol drinking or 10\% ethanol/water 2-bottle choice week, nor were there any significant group differences in water intake or ethanol preference.

Electrophysiology. Mouse coronal NAc slices $(400 \mu \mathrm{m})$ were prepared as described previously (Crowder et al., 2002) using a Leica VT1000S Vibratome. Subjects were chronically treated with saline for $21 \mathrm{~d}$ or with ethanol and then classified as sensitized or nonsensitized (see above). Eleven to $20 \mathrm{~d}$ after the $21 \mathrm{~d}$ treatment regimen, mice were anesthetized with halothane, decapitated, and the brain was quickly isolated and immersed in ice-cold artificial CSF (ACSF) containing the following (in $\mathrm{mm}): 126 \mathrm{NaCl}, 3 \mathrm{KCl}, 1.5 \mathrm{MgCl}_{2}, 2.4 \mathrm{CaCl}_{2}, 1.2 \mathrm{NaH}_{2} \mathrm{PO}_{4}, 11$ glucose, and $26 \mathrm{NaHCO}_{3}, \mathrm{pH} 7.4$, saturated with $95 \% \mathrm{O}_{2} / 5 \% \mathrm{CO}_{2}$. Brain slices were allowed to recover for at least $1.5 \mathrm{~h}$ in ACSF at room temperature before recording. Slices were maintained at room temperature until being transferred to a submersion-type recording chamber. Whole-cell patch recordings of NAc neurons were performed using micropipettes (8-13 $\mathrm{M} \Omega$ ) made from $1.5 \mathrm{~mm}$ borosilicate glass (Sutter Instrument). Recording pipettes were filled with an internal solution containing the following (in $\mathrm{mm}$ ): 117 Cs-methanesulfonate, $15 \mathrm{CsCl}, 8 \mathrm{NaCl}, 10$ tetraethylammonium-Cl (TEA), 0.2 EGTA, 10 HEPES, 2 ATP, 0.3 GTP, and QX-314 [N-(2,6-dimethylphenylcarbamoylmethyl) triethylammonium chloride], pH 7.25 (290-295 mOsm). Recordings were obtained using an AxoClamp 2B amplifier (Molecular Devices), digitized (Molecular Devices), and analyzed using pClamp 9.0 software (Molecular Devices). Evoked EPSCs were generated by stimulating the region just dorsal to the anterior commissure using a concentric bipolar electrode (FHC) and a stimulus isolation unit (AMPI). Access resistance was frequently checked using a $-10 \mathrm{mV}$ voltage step. Only cells with a stable access resistance of $<25 \mathrm{M} \Omega$ were used in the experimental analyses. In all experiments, GABA ${ }_{A}$ IPSCs were blocked using bicuculline methiodide (20 $\mu \mathrm{M}$; Sigma). NAc neurons were voltage clamped at $-90 \mathrm{mV}$ and evoked EPSCs $(0.05 \mathrm{~Hz})$ were recorded for at least $10 \mathrm{~min}$ to ensure the stability of baseline recordings. The paired-pulse ratio (PPR) of EPSCs $(25,50$, and $250 \mathrm{~ms}$ interpulse interval) was then measured and $6 \mathrm{~min}$ of spontaneous EPSCs (sEPSCs) were collected to assess possible presynaptic and postsynaptic alterations associated with locomotor sensitization.

AMPA/NMDA ratios were then determined using a method similar to one described previously (Myme et al., 2003). Briefly, the time course of AMPA EPSCs was assessed by stimulating while the cell was held at -90 $\mathrm{mV}$. Then the slice was stimulated while the cell was voltage clamped at $+40 \mathrm{mV}$ after two $1 \mathrm{~min}$ voltage steps to $-40 \mathrm{mV}$ and $+10 \mathrm{mV}$. Holding the cell at $+40 \mathrm{mV}$ provided sufficient depolarization and driving force to reveal the NMDA receptor component of evoked EPSCs. Averages of 10 EPSCs evoked at $-90 \mathrm{mV}$ and $+40 \mathrm{mV}$ were then used to determine the AMPA/NMDA ratio. To validate the AMPA/NMDA ratio, the relative contribution of AMPARs and NMDARs to evoked EPSCs was assessed. In cells voltage-clamped at $+40 \mathrm{mV}$, the peak AMPA response was assessed during a $2 \mathrm{~ms}$ window, $14 \mathrm{~ms}$ after the stimulus artifact, corresponding to the peak AMPA response recorded at $-90 \mathrm{mV}$. The peak NMDA response was recorded during a $10 \mathrm{~ms}$ window, $100 \mathrm{~ms}$ after the stimulus artifact. Bath application of $20 \mu \mathrm{M}$ DNQX significantly decreased the AMPA receptor current by $>60 \%$ and had no effect on the peak response recorded during 
the "NMDA window." Subsequent application of $50 \mu \mathrm{M}$ APV completed abolished the remaining currents in both windows (data not shown). This experiment confirmed that the peak current recorded at $+40 \mathrm{mV}$ during the "AMPA window" was mediated predominantly by activation of AMPA receptors and the peak current recorded during the NMDA window was mediated solely by NMDA receptor activation. $I_{\mathrm{AMPA}}$ at $+40 \mathrm{mV} / I_{\mathrm{NMDA}}$ at $+40 \mathrm{mV}$ was taken as the AMPA/NMDA ratio. However, this determination of the AMPA/NMDA ratio may be influenced by ethanol-mediated changes in glutamate receptor kinetics.

Nucleus accumbens medium spiny neurons express a form of low frequency, NMDA receptor-dependent LTD. Indeed, it has already been demonstrated that NMDAR antagonist pretreatment can attenuate the induction of LTD in NAc neurons (Kombian and Malenka, 1994; Kasanetz et al., 2010). To assess the effect of behavioral sensitization on NMDAR-dependent LTD, recordings were made from other NAc core and shell neurons from each of the three treatment groups. After a $10 \mathrm{~min}$ baseline at $-90 \mathrm{mV}$, LTD was induced using a pairing protocol, as described previously (Martin et al., 2006): $3 \times 5 \mathrm{~Hz}$ for $3 \mathrm{~min}$ paired with a depolarization to $-50 \mathrm{mV}$ and a $5 \mathrm{~min}$ intertrain interval. LTD was quantified as the percentage decrease in the maximal EPSC amplitude recorded 15-30 min after LTD induction relative to baseline EPSC amplitude. Considering that similar protocols can also induce NMDA receptor-independent forms of LTD in the NAc (Robbe et al., 2002), recordings were also made from NAc core neurons in slices from the three treatment groups in the presence of the NMDA receptor antagonist APV $(50 \mu \mathrm{M})$ using the same LTD protocol described above. LTD was also recorded in NAc core neurons in mice after exposure to one administration of saline or ethanol.

Specific experiments to confirm the identity of the neurons studied were not performed. However, $95 \%$ of neurons in the NAc are medium spiny neurons and recordings were only made from neurons with an initial resting membrane potential $\leq-70 \mathrm{mV}$.

Western blots. NAc tissue (core and shell combined) was isolated from brain slices prepared using a protocol identical to that described for electrophysiological studies. Lysis buffer (50 mm Tris, pH 7.4, 0.5\% SDS, $1 \mathrm{~mm}$ EDTA, $\mathrm{pH}$ 8), and protease inhibitors for mammalian tissue (Sigma) were added at $12 \mu \mathrm{l} / \mathrm{mg}$ tissue and tissue was disrupted by brief sonication and incubated at $4^{\circ} \mathrm{C}$ on a rotisserie mixer for $2 \mathrm{~h}$. Protein yield was quantified using a BCA assay (Thermo Scientific). Twenty micrograms of total protein was loaded per column onto $4-20 \%$ Criterion TGX precast polyacrylamide gels (Bio-Rad), separated, and transferred to a nitrocellulose membrane (Hybond N; GE Healthcare). The membrane was blocked with Tris buffered saline (TBS)-T (150 mM NaCl, 5.2 mu Na${ }_{2} \mathrm{HPO}_{4}, 1.7 \mathrm{~mm} \mathrm{KH}_{2} \mathrm{PO}_{4}, 0.05 \%$ Tween 20 ) containing $5 \%$ nonfat dry milk (NFM). Subsequently, blots were incubated overnight at $4^{\circ} \mathrm{C}$ in TBS-T/0.5\% NFM containing a rabbit polyclonal or mouse monoclonal primary antibody (all Millipore) that recognized the NMDAR1 subunit: mouse anti-GluN1, 1:500 dilution (catalog \#MAB1586); rabbit antiGluN2A, 1:3000 dilution (catalog \#AB1555); mouse anti-GluN2B, 1:5000 dilution (catalog \#MAB5778); or rabbit anti-GluA2/3, $0.3 \mu \mathrm{g} / \mathrm{ml}$ dilution (catalog \#AB1506). After extensive washing with TBS-T, the blots were exposed to peroxidase-labeled goat anti-rabbit or goat antimouse secondary antibody (Sigma) at a 1:3000 dilution in TBS-T/0.5\% NFM for $1 \mathrm{~h}$ at room temperature with agitation. Detection of bound secondary antibody was performed using Super Signal West Dura Extended Duration Substrate enhanced chemiluminescence (Thermo Scientific). To normalize expression between experiments, the blots were probed with mouse monoclonal antibody directed against three housekeeping proteins ( $\beta$-actin, $\beta$-tubulin, and voltage-dependent anionselective channel, a genomically encoded mitochondrial protein, at 1:50,000-1:100,000 dilutions; Millipore), followed by peroxidaselabeled goat anti-mouse secondary antibody, 1:10,000 dilution (Sigma). Band intensity was visualized and quantified using the Chemi-Doc XRS and Quantity One Analysis software (Bio-Rad). To examine surface expression of specific NMDA receptor subunits, the membraneimpermeable cross-linker bis(sulfosuccinimidyl) suberate (BS3; Thermo Fisher Scientific) was used as described previously (Grosshans et al., 2002) with slight modifications. Slices from individual saline, nonsensitized, and sensitized mice were allowed to stabilize for $1 \mathrm{~h}$ after prepara- tion and subsequently transferred to ACSF $\pm 1 \mathrm{mg} / \mathrm{ml} \mathrm{BS} 3$ and allowed to incubate for $1 \mathrm{~h}$ at $4^{\circ} \mathrm{C}$. Slices were then rinsed three times with ACSF containing $20 \mathrm{~mm}$ Tris, $\mathrm{pH}$ 7.4. NAc tissue samples were dissected and frozen at $-80^{\circ} \mathrm{C}$ until tissue was used for Western blot analysis. Western blot methods were the same as described above, except that $20 \mu \mathrm{g}$ of total protein was loaded onto precast $8-16 \%$ SDS-polyacrylamide gels. BS3-insensitive intracellular protein was compared with total protein from the samples not incubated with BS3 collected in parallel to calculate the percentage of protein found on the surface for each animal.

Statistics. Locomotor activity recorded during the chronic treatment test days and ethanol drinking during the two-bottle choice protocol were analyzed by a repeated-measures ANOVA with group (saline, sensitized, and nonsensitized mice) as the independent factor. The acute locomotor response to ethanol challenge was analyzed by one-way ANOVA with group (saline, low responders, and high responders) as the independent factor. For the electrophysiological studies, data were analyzed by one-way ANOVA using group (saline, sensitized and nonsensitized mice, saline, low responders, and high responders) as the independent factor. For the Western blot experiments, the total and percentage of "cell surface" receptor expression from individual animals were averaged within the treatment groups and compared using one-way ANOVA. In all studies, Newman-Keuls tests for multiple comparisons were used for post hoc analyses when the ANOVA detected a significant effect. The level of significance was set at $p<0.05$ in all analyses.

\section{Results}

\section{EtOH sensitization increases ethanol drinking}

To induce locomotor sensitization, male Swiss Webster mice received daily injections of $1.8 \mathrm{~g} / \mathrm{kg}$ ethanol or saline for $21 \mathrm{~d}$. Two distinct behavioral profiles were observed after this treatment regimen (Fig. 1A): some mice developed robust sensitization after the ethanol treatments (sensitized mice), whereas other subjects receiving the same ethanol injections showed no significant increase in locomotor activity (nonsensitized mice), instead displaying a locomotor response similar to that of saline-treated controls. The repeated-measures ANOVA revealed significant effects of group $\left(F_{(2,79)}=112.38, p<0.001\right)$, test $\left(F_{(3,237)}=7.90\right.$, $p<0.001)$, and group-test interaction factors $\left(F_{(6,237)}=11.53\right.$, $p<0.001)$. The Newman-Keuls post hoc test detected that the sensitized group displayed a progressive increase in locomotor activity levels, exhibiting higher ambulatory distance than their initial levels in the previous test $(p<0.05$, Fig. $1 A)$. In addition, the sensitized group showed higher activity than the saline and nonsensitized groups in all tests performed $(p<0.05)$. There were no significant differences between nonsensitized and saline groups. The percentage increase in locomotion was higher in the sensitized mice than in the other groups, as revealed by one-way $\operatorname{ANOVA}\left(F_{(2,79)}=8.04, p<0.001\right.$; Fig. $\left.1 B\right)$.

It was demonstrated recently that previous ethanol exposure can lead to an increase in ethanol self-administration (a behavioral marker of addiction vulnerability) (Fidler et al., 2011). To determine whether there was any association between the development of locomotor sensitization and ethanol drinking in Swiss Webster mice, voluntary ethanol consumption in saline, nonsensitized, and sensitized mice was examined. Ethanol drinking was assessed $14 \mathrm{~d}$ after the locomotor sensitization protocol. During the week that mice had free choice between water and 20\% ethanol, sensitized mice drank significantly more ethanol than nonsensitized mice and, notably, no differences in ethanol intake were observed between nonsensitized mice and saline-treated control groups (Fig. 1C). The repeated-measures ANOVA detected a significant effect of group $\left(F_{(2,13)}=15.40, p<0.001\right)$ and drinking day $\left(F_{(4,52)}=5.76, p<0.001\right)$, but not the groupdrinking day interaction $\left(F_{(8,52)}=1.30\right)$. The post hoc test for the 

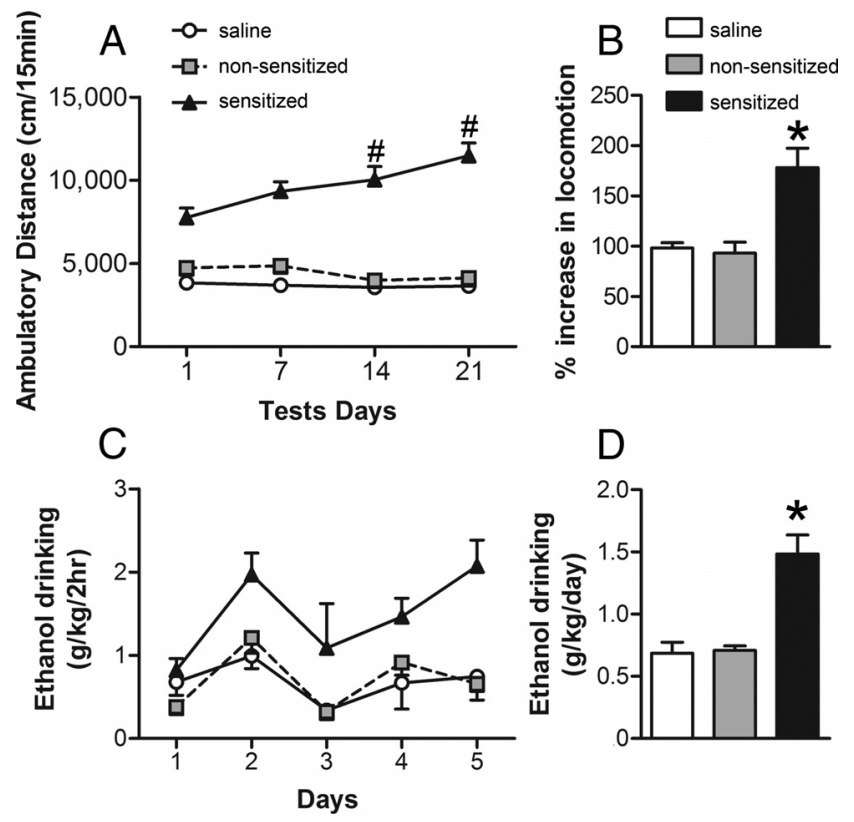

Figure 1. Development of behavioral sensitization to ethanol is associated with increased voluntary ethanol consumption. Mice were treated daily with ethanol $(1.8 \mathrm{~g} / \mathrm{kg}, \mathrm{i} . \mathrm{p} ., n=54)$ or saline ( $n=28$ ) for 21 consecutive days. $\boldsymbol{A}$, Ambulatory distance during 15 min tests immediately after injections on days $1,7,14$, and 21 . Mice in the upper and lower tertile on day 21 were classified as sensitized ( $n=27$ ) or nonsensitized ( $n=27)$, respectively. Sensitized mice displayed a progressive increase in activity across days ( ${ }^{\#} p<0.05$, sensitized in test 3 or 4 vs sensitized in test 1). $\boldsymbol{B}$, Percentage increase in locomotor response on day 21 relative to day 1. Sensitized mice displayed higher locomotor activity than the other two groups. ${ }^{*} p<0.05$. $\boldsymbol{C}$, Daily ethanol intake for the three treatment groups during a modified Drinking in the Dark procedure (2 h, 2-bottle choice; $20 \%$ ethanol v/v, and water). Sensitized mice drank significantly more ethanol than nonsensitized and saline subjects $(p<0.05)$. $\boldsymbol{D}$, Average ethanol intake for the three treatment groups. $p<0.05$ for sensitized versus nonsensitized and saline groups.

group factor revealed that sensitized mice drank more ethanol than the other two groups (Fig. $1 D ; p<0.05$ ).

\section{EtOH sensitization induces decreased NMDA function and expression}

As noted earlier, synaptic alterations in the NAc are thought to play a central role in the etiology of addiction (Ikemoto, 2010). Because NAc glutamatergic synapses may be particularly sensitive to chronic exposure to drugs of abuse (Vanderschuren and Kalivas, 2000), we next sought to determine whether measures of NAc glutamate receptor function and expression were associated with individual differences in ethanol locomotor sensitization. Cohorts of saline, nonsensitized, and sensitized mice were killed 11-20 d after the sensitization procedure and NAc slices were prepared for whole-cell patch-clamp recordings from NAc core neurons. We first examined sEPSCs to assess whether presynaptic release probability (sEPSC frequency) was associated with sensitization to ethanol. We found no difference in the frequency of sEPSCs among the groups (one-way ANOVA: $F_{(2,23)}=0.28$; Fig. $2 A)$. We also examined PPRs of evoked AMPA receptormediated EPSCs. No significant group differences in PPR were observed (repeated-measures ANOVA: group $F_{(2,39)}=0.70$; stimulus interval $F_{(2,78)}=9.57, p<0.05$; group-stimulus interval interaction $F_{(4,78)}=0.50$; Fig. $\left.2 D\right)$. These results suggest that locomotor sensitization to ethanol is not associated with presynaptic alterations in glutamatergic synaptic transmission. We next investigated whether variability in ethanol sensitization was asso- ciated with alterations in postsynaptic glutamate receptor function in the NAc core. The analyses of sEPSCs revealed no group differences in the amplitude of sEPSCs (one-way ANOVA: $F_{(2,23)}$ $=1.00$; Fig. $2 B$ ), providing initial evidence that direct alterations in AMPA receptor function may not be associated with locomotor sensitization to ethanol. There were also no statistically significant differences in the average cumulative probability distributions of sEPSC amplitudes among the treatment groups (assessed by K-S tests; Fig. 2C). We did, however, observe a significant increase in the AMPA/NMDA ratio in cells from ethanol-sensitized mice compared with the nonsensitized and saline groups (one-way ANOVA: $F_{(2,18)}=6.71, p<0.05$; Fig. $2 E, F)$. Because there were no significant group differences in any presynaptic (PPR and sEPSC frequency) or postsynaptic (sEPSC amplitude) measures of AMPA receptor activity, we inferred that ethanol-sensitized mice may have an impairment in NAc core NMDA receptor function.

To further test this hypothesis, we also examined the expression of glutamate receptor subunits using NAc tissue isolated from subjects in each of the three groups. Sensitized mice had a significant decrease in NMDA GluN1 subunit expression relative to nonsensitized or control subjects (one-way ANOVA: $F_{(2,15)}=$ 7.33, $p<0.05$; Fig. $3 A$ ). We also found a significant decrease in NMDA GluN2A subunit expression (one-way ANOVA: $F_{(2,15)}=$ $21.04, p<0.001$; Fig. $3 C$ ) and a significant increase of NMDA GluN2B subunit expression in the sensitized mice (one-way ANOVA: $F_{(2,15)}=6.38, p<0.05$; Fig. $\left.3 D\right)$. We next used the membrane-impermeable cross-linker BS3, as described previously (Diaz et al., 2011), to examine surface expression of NMDA receptor subunit proteins. Sensitized mice also had significantly lower surface expression of NMDA GluN1 subunit protein relative to the other two groups (one-way ANOVA: $F_{(2,15)}=17.66$, $p<0.001$; Fig. $3 B$ ). No differences in total or surface expression of the GluN1 subunit were observed between the nonsensitized and saline mice. No group differences in surface expression were found for either the NMDA GluN2A (one-way ANOVA: $F_{(2,15)}=$ 0.36; Fig. $3 D$ ) or GluN2B (one-way ANOVA: $F_{(2,15)}=0.91$; Fig. $3 F$ ) groups. Considering that GluN1 is the constitutive subunit of NMDA receptors, these data, along with the electrophysiological results, provide further evidence that locomotor sensitization to ethanol is associated with a selective disruption of NAc NMDA receptor function and expression. No group differences in the surface expression of AMPA GluA2/3 subunits were observed (one-way ANOVA: $F_{(2,15)}=0.36$; Fig. $3 G$ ).

\section{Ethanol sensitization is associated with impairment in NMDA receptor-dependent LTD in NAc core}

Given that the synapses made by cortical afferents onto medium spiny neurons can express NMDA receptor-dependent LTD (Thomas et al., 2000) and may be an important substrate associated with drug seeking (Martin et al., 2006), we predicted that the expression of this form of synaptic plasticity would be reduced in ethanol-sensitized mice. Robust LTD was observed in both the saline-treated mice and nonsensitized groups. However, the magnitude of LTD in the NAc core was significantly lower in the sensitized group (one-way ANOVA: $F_{(2,19)}=10.99, p<$ 0.001 ; Fig. $4 A-C$ ). Low-frequency stimulation protocols can also induce NMDA receptor-independent forms of LTD in the NAc (e.g., endocannabinoid-dependent LTD; Robbe et al., 2002). To determine whether the ethanol locomotor sensitizationassociated deficit in LTD was dependent on NMDA receptor activation, we repeated the above experiment in the presence of the NMDA receptor antagonist APV. Significant LTD was observed 

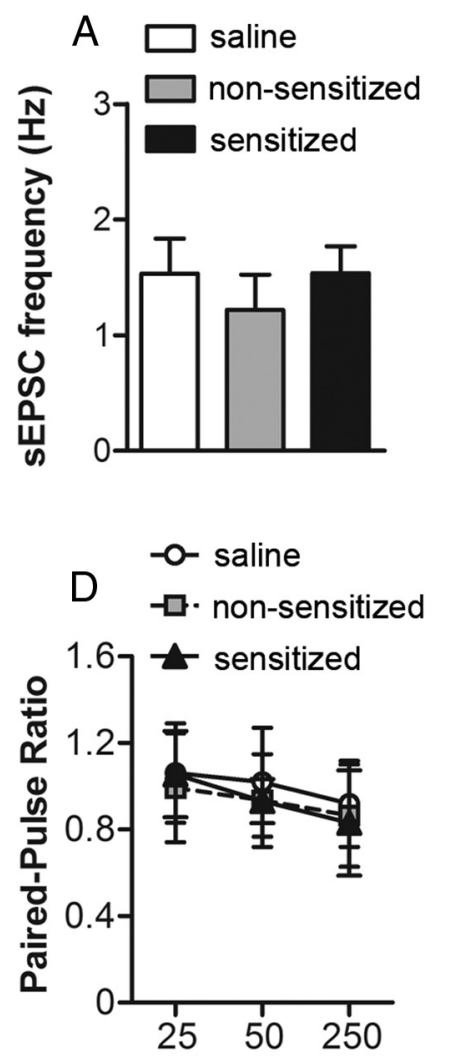

Interstimulus interval (ms)
B

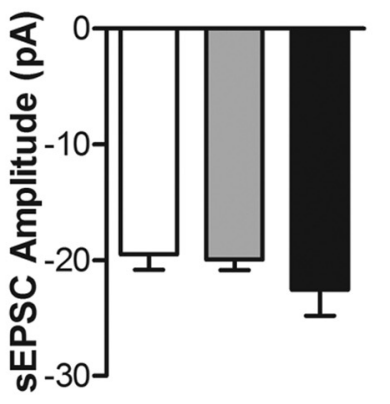

$\mathrm{E}$

C

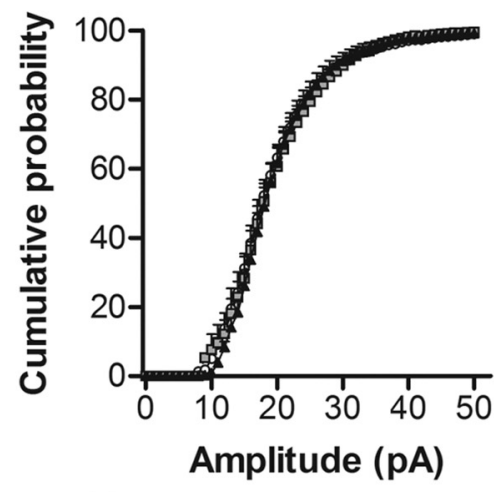

$\mathrm{F}$
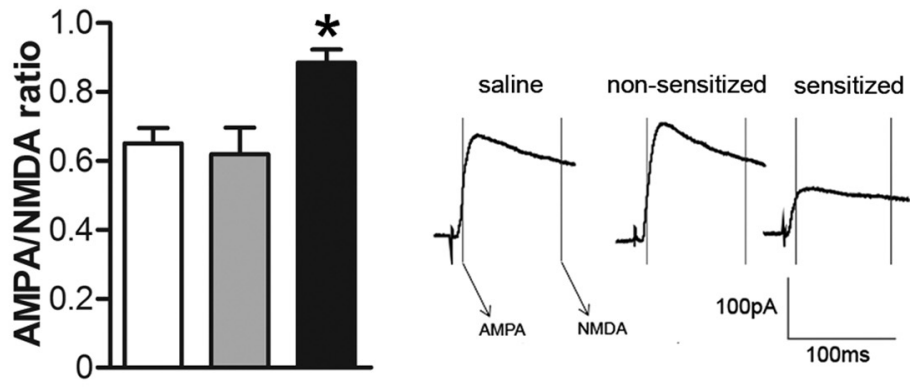

Figure 2. The development of ethanol locomotor sensitization results in decreased NAc core NMDA receptor function. For $\boldsymbol{A}-\boldsymbol{D}$, NAc core neurons were voltage clamped at $-90 \mathrm{mV}$ and for $\boldsymbol{E}-\boldsymbol{F}$

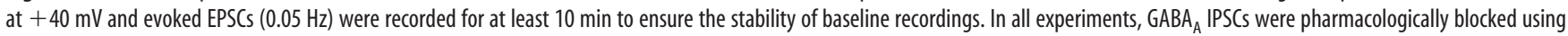
bicuculline methiodide (20 $\mu \mathrm{m}$; Sigma). $\boldsymbol{A}, \boldsymbol{B}$, Average frequency $(\boldsymbol{A})$ and amplitude of sEPSCS (B) collected during 6 min epochs at $-90 \mathrm{mV}$ from cells in slices from saline ( $n=12$ cells in 8 mice), nonsensitized ( $n=6$ cells in 6 mice), and sensitized ( $n=8$ cells in 8 mice) groups. C, Cumulative probability distributions of sEPSC amplitude obtained in recordings from saline, nonsensitized, and sensitized groups of mice. D, PPR of evoked EPSCs (25,50, and $250 \mathrm{~ms}$ interpulse interval) at $-90 \mathrm{mV}$ from saline ( $n=15$ cells in 9 mice), nonsensitized ( $n=12$ cells in 9 mice), and sensitized ( $n=$ 12 cells in 9 mice) groups. $\boldsymbol{E}$, Averages of 10 consecutive EPSCs evoked at $+40 \mathrm{mV}$ for AMPA/NMDA ratios for saline, nonsensitized, and sensitized groups. Peak AMPA receptor-mediated current was measured at $+40 \mathrm{mV}$ (during a $2 \mathrm{~ms}$ window, $13 \mathrm{~ms}$ after EPSC onset) and NMDA receptor-gated currents were measured in a $10 \mathrm{~ms}$ window, $100 \mathrm{~ms}$ after EPSC onset. $\boldsymbol{F}$, AMPA/NMDA ratios in cells

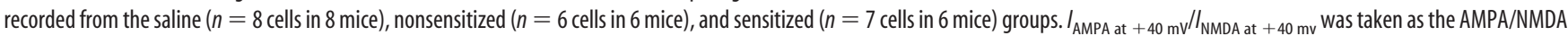
ratio. ${ }^{*} p<0.05$ for sensitized versus nonsensitized and saline groups.

in slices from all three groups; however, no differences in the magnitude of NMDA receptor-independent LTD were observed among saline, nonsensitized, and sensitized animals (one-way ANOVA: $F_{(2,17)}=0.12$; Fig. $\left.4 F\right)$. Finally, because the NAc core and shell are thought to play important, albeit distinct, roles in the pathophysiology of alcohol addiction, we also examined the effect of the sensitization protocol on LTD in NAc shell neurons. In contrast to our findings in the core, no differences among the treatment groups were noted in the induction or expression of LTD in NAc shell recordings (one-way ANOVA: $F_{(2,15)}=1.39$; Fig. $4 G)$.

In some cohorts, we detected a significant difference in the initial locomotor stimulant effect of ethanol (treatment day 1) between mice that were eventually classified as nonsensitized and sensitized. This difference was correlated with the observed individual variability in the development of locomotor sensitization to ethanol. To determine whether the synaptic alterations associated with locomotor sensitization were dependent on the initial acute effect of ethanol on locomotor activity, we conducted a separate experiment to determine whether there were any differences in the expression of LTD in animals classified as "low" and "high" responders after a single acute ethanol challenge. Twentyfour hours after a 15 min baseline assessment of horizontal loco- motor activity, mice received a single intraperitoneal injection of saline or $1.8 \mathrm{~g} / \mathrm{kg}$ ethanol and were immediately placed in the locomotor activity boxes for $15 \mathrm{~min}$. Based on their locomotor response on the acute test day, ethanol-treated mice were classified as "high responders" (activity scores in the upper 33\% of the distribution) or "low responders" (activity scores in the lower $33 \%$ of the distribution) (Fig. 4D). The intermediate group was discarded. Assessment of LTD in NAc core neurons in saline, low responders, and high responders was conducted 11-20 d after the acute locomotor activity test, as described above. No differences in the magnitude of LTD were observed among the three treatment groups (one-way ANOVA: $F_{(2,24)}=0.60$; Fig. $4 E$ ). These data demonstrate that the disruption of NMDA receptordependent LTD in the NAc core observed in sensitized mice was not related to a difference in initial locomotor response to ethanol. Rather, reduced LTD was only observed after the development of the ethanol-associated behavioral plasticity.

\section{Discussion}

Locomotor sensitization is an animal model that has been used frequently to study adaptive changes associated with the transition from controlled drug use to abusive use (Sanchis-Segura and Spanagel, 2006). Although the specific role of locomotor sensiti- 

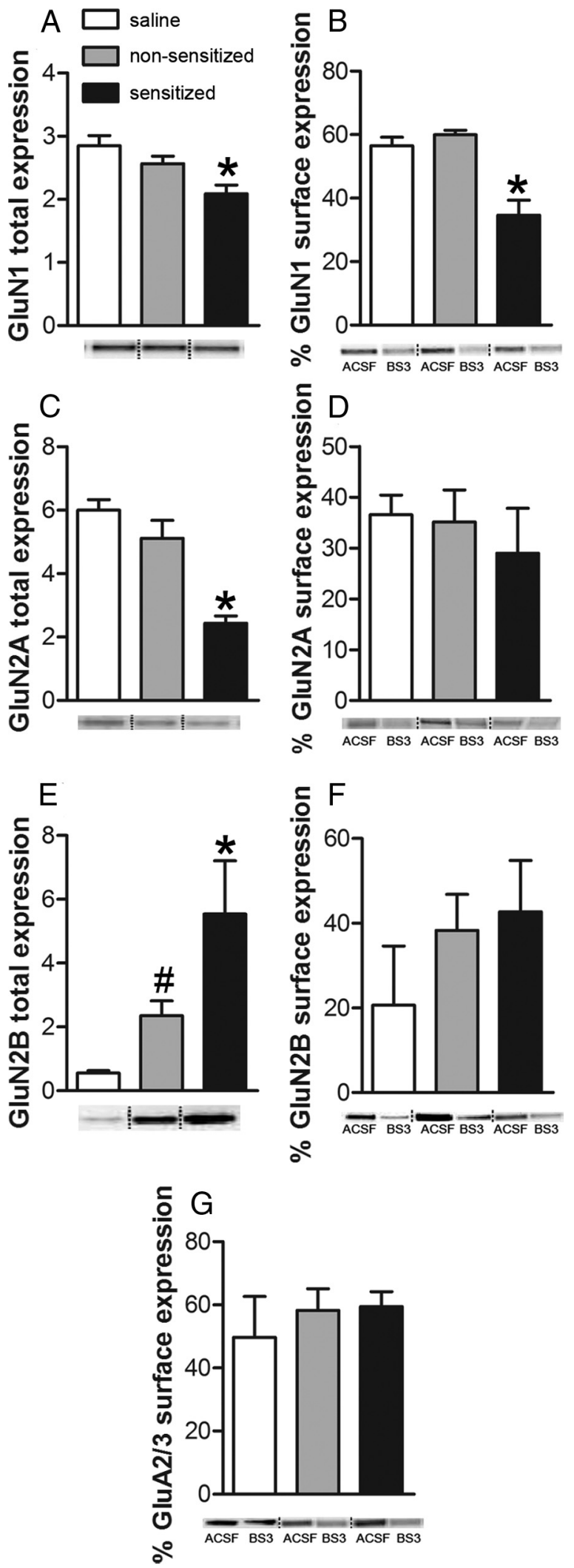

Figure 3. The development of ethanol locomotor sensitization results in decreased NAC NMDA receptor surface expression. Two weeks after the end of ethanol or saline treatment, NAC tissue was isolated from brain slices prepared using a protocol identical to that described for the electrophysiological studies. The slices were divided and incubated in either ACSF (total expression) or BS3-ACSF (internal expression). Graphs on the left are representative of total expression in arbitrary units; graphs on the right are representative of percentage surface expression. $A$, Average total accumbal GluN1 expression in saline $(n=6)$, nonsensitized $(n=6)$, and sensitized zation in the addiction process remains unclear, this form of behavioral plasticity involves some of the same neural circuits, neurotransmitters, and receptors as other animal models of addiction (Steketee and Kalivas, 2011). Therefore, there is much interest in elucidating the neural substrates that contribute to the development of this form of behavioral plasticity. A number of prior studies have demonstrated large individual differences in the development of locomotor sensitization to ethanol in outbred Swiss Webster mice (Souza-Formigoni et al., 1999; Quadros et al., 2002; Abrahao et al., 2011). Because these differences are not due to alterations in ethanol metabolism (Quadros et al., 2005), this model may prove useful in identifying neural correlates of vulnerability and resilience to ethanol-induced locomotor sensitization. Indeed, in the present study, we confirmed in multiple cohorts of Swiss Webster mice that a standard ethanol sensitization treatment regimen consistently generates groups of mice that display a robust increase in ethanol-stimulated locomotor activity, as well as other groups of mice that are resilient to this form of behavioral plasticity (nonsensitized).

A number of other elegant studies have demonstrated how individual differences in responsivity to drugs of abuse can be used to identify behavioral and neurobiological correlates of addiction vulnerability, particularly with respect to psychostimulants (Gulley et al., 2003; Deroche-Gamonet et al., 2004; Kasanetz et al., 2010). We therefore sought to take advantage of the robust individual differences in locomotor sensitization after repeated ethanol treatments to examine the relationships among ethanol sensitization, voluntary ethanol drinking behavior, and glutamatergic synaptic function and plasticity after a protracted withdrawal. Mice that developed robust locomotor sensitization to ethanol voluntarily consumed more ethanol than saline-treated controls or ethanol-treated mice resilient to locomotor sensitization. Ethanol-sensitized mice also exhibited significant decreases in accumbal NMDA receptor expression and function relative to nonsensitized and control mice and ethanol sensitization was also associated with a significant impairment in NMDA receptordependent LTD in the core, but not the shell, of the NAc. These studies suggest that deficits in NAc core NMDA receptor signaling and glutamatergic plasticity contribute to individual differences in the development of locomotor sensitization to ethanol.

Chronic ethanol exposure and the development of locomotor sensitization can lead to significant increases in voluntary ethanol drinking (Lessov et al., 2001; Becker and Lopez, 2004; Fidler et al., 2011; Carrara-Nascimento et al., 2012). Increased ethanol consumption, like locomotor sensitization, may represent an important behavioral marker of addiction vulnerability. Our data reveal that ethanol-sensitized mice consume more ethanol than control subjects or ethanol-treated mice that failed to develop this form

\footnotetext{
$\leftarrow$

$(n=6)$ tissue isolates. ${ }^{*} p<0.05$ for sensitized versus nonsensitized and saline groups. $\boldsymbol{B}$, Average percentage of GluN1 subunit surface expression in NAc tissue isolates from saline ( $n=$ 6), nonsensitized ( $n=6)$, and sensitized $(n=6)$ groups. ${ }^{*} p<0.05$ for sensitized versus nonsensitized and saline groups. C, Average total accumbal GluN2A expression in saline ( $n=$ 6), nonsensitized ( $n=6$ ), and sensitized ( $n=6$ ) tissue isolates. ${ }^{*} p<0.05$ for sensitized versus nonsensitized and saline groups. $\boldsymbol{D}$, Average percentage GluN2A subunit surface expression in NAc tissue isolates from saline $(n=6)$, nonsensitized $(n=6)$, and sensitized $(n=6)$ groups. $E$, Average total accumbal GluN2B expression in saline $(n=6)$, nonsensitized $(n=6)$, and sensitized $(n=6)$ tissue isolates ${ }^{*} p<0.05$ for sensitized versus nonsensitized and saline groups; $" \not p<0.05$ for nonsensitized versus saline groups. $\boldsymbol{F}$, Average percentage GluN2B subunit surface expression in NAc tissue isolates from saline $(n=6)$, nonsensitized $(n=6)$, and sensitized ( $n=6$ ) groups. G, Average percentage GluA2/3 subunit surface expression in NAc tissue isolates from saline $(n=6)$, nonsensitized $(n=6)$, and sensitized $(n=6)$ groups.
} 
A

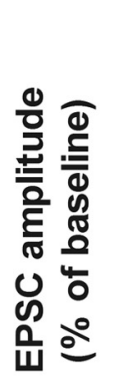$$
\text { A }
$$

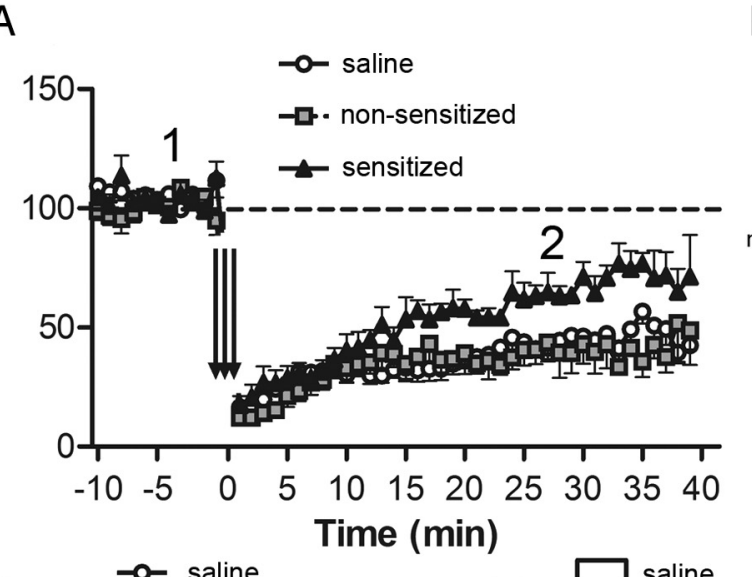

B

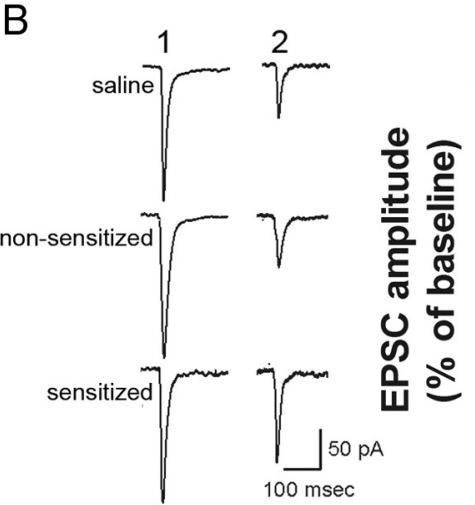

C
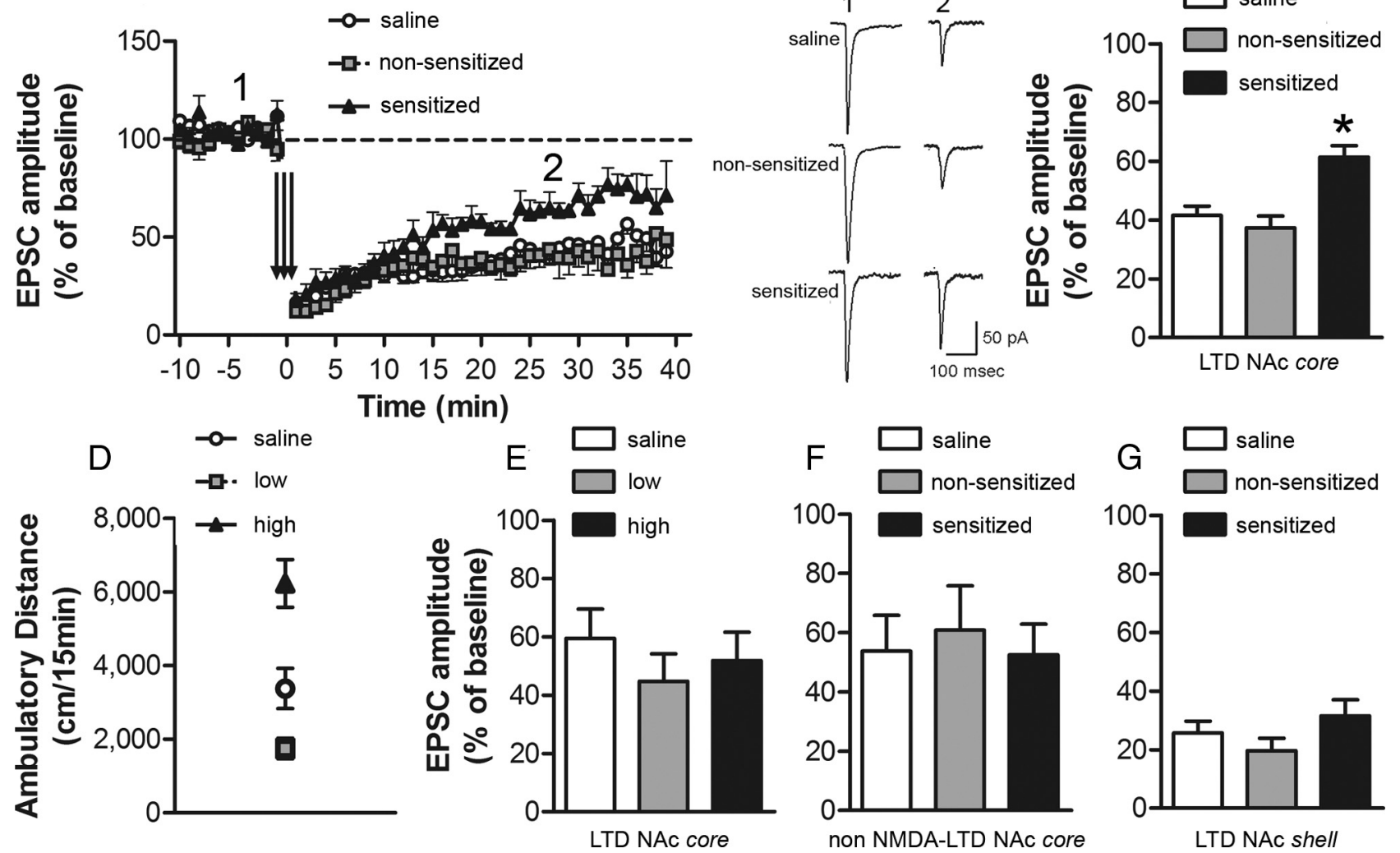

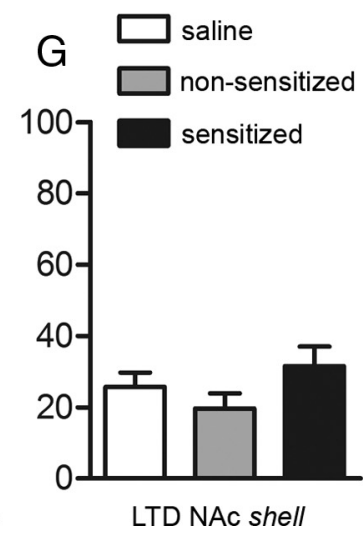

Figure 4. Impairment of NAccore NMDA-dependent LTD in ethanol-sensitized mice. NAcneurons were voltage clamped at $-90 \mathrm{mV}$. LTD was induced using a pairing protocol: $3 \times 5 \mathrm{~Hz}$ for 3 min, paired with a depolarization to $-50 \mathrm{mV}$ with a 5 min intertrain interval. EPSC amplitude (mean \pm SEM) was measured as the maximal response $15-30$ min after LTD induction. $A$, Time course of NAc core LTD in cells recorded from saline ( $n=9$ cells in 7 mice), nonsensitized ( $n=7$ cells in 6 mice), and sensitized ( $n=6$ cells in 6 mice) groups. $\boldsymbol{B}$, Representative EPSCs before (1) and after ( 2 ) the NAc core LTD protocol $(\boldsymbol{A})$ for the three treatment groups. C, EPSC amplitude (\% baseline) after NAc core LTD induction. ${ }^{*} p<0.05$ for sensitized versus nonsensitized and saline groups. The magnitude of LTD was significantly lower in cells recorded from ethanol-sensitized mice compared with cells from nonsensitized and saline groups. $\boldsymbol{D}$, Ambulatory distance during a 15 min test immediately after intraperitoneal administration of saline $(n=6)$ or ethanol $1.8 \mathrm{~g} / \mathrm{kg}$. Based on their locomotor response to a single ethanol injection, ethanol-treated mice were classified as low responders (lower tertile; $n=6$ ) or high responders (upper tertile; $n=6$ ). ${ }^{*} p<0.05$ for high versus low responders and saline groups. E, EPSC amplitude (\% baseline) after NAC core LTD induction. No difference in the magnitude of LTD was observed in cells recorded from ethanol high responders, ethanol low responders, or saline-treated mice. $F$, EPSC amplitude (\% baseline) after NAc core NMDA-independent LTD induction (recorded in the presence of the NMDA receptor antagonist APV $50 \mu \mathrm{m}$ ). No difference in the magnitude of NMDA-independent LTD was observed in cells recorded from the saline $(n=7)$, ethanol nonsensitized $(n=7)$, and sensitized $(n=6)$ groups. $G$, EPSC amplitude (\% baseline) after NAc shell LTD induction. No difference in the magnitude of LTD was observed in cells recorded from the saline $(n=5)$, nonsensitized $(n=5)$, and sensitized $(n=8)$ groups.

of behavioral plasticity. These findings demonstrate that the development of locomotor sensitization, and not solely the chronic ethanol treatment regimen, is associated with increased ethanol drinking behavior.

NMDA receptors are known to play an important role in ethanol dependence, withdrawal, craving, and relapse (Trujillo and Akil, 1995; Krystal et al., 2003). Acute ethanol treatment inhibits NMDA receptor function (Lovinger et al., 1989; Simson et al., 1991). In contrast, chronic ethanol exposure has been shown to result in an increased density of NMDARs and a facilitation of receptor function in several brain regions (Nagy, 2008), including the dorsal striatum (Wang et al., 2010) and NAc (Quadros et al., 2002; Zhou et al., 2007). Most prior studies have examined NMDA receptor expression or function in very early stages of withdrawal, between 2 and $24 \mathrm{~h}$ after the last ethanol exposure (Quadros et al., 2002; Zhou et al., 2007; Nagy, 2008). Surprisingly, our present data suggest that after a prolonged withdrawal period (11-20 d), measures of NMDA receptor expression and function in the NAc are significantly reduced in ethanolsensitized mice relative to nonsensitized and control subjects. Whole tissue and surface expression of the functionally obligatory GluN1 subunit of the glutamatergic NMDA receptor were significantly lower in NAc tissue isolated from sensitized mice relative to the other two groups, with no effect of treatment group on GluN2A, GluN2B, or AMPA-GluA2/3 surface expression. Moreover, locomotor sensitization to ethanol was not associated with any differences in presynaptic or postsynaptic measures of AMPA receptor-mediated sEPSCs, but AMPA/NMDA ratios were larger in recordings from sensitized mice. Although we were not able to obtain a direct measure of NMDA receptor function in these studies, the most parsimonious interpretation of these biochemical and electrophysiological data is that the development of ethanol locomotor sensitization is associated with a reduction in NAc NMDA receptor function.

Because these sensitization-related synaptic alterations were observed during a time period that was also associated with increased ethanol drinking, these data suggest that a downregulation of NAc NMDA receptor activity may represent a previously unrecognized synaptic correlate associated with increased vulnerability to alcohol addiction. In fact, heterozygous deletion of the GluN1 subunit in mice is associated with increased ethanol consumption (Du et al., 2012). A recent study also showed reduced expression of GluN1 subunit in medial prefrontal cortex tissue $3 \mathrm{~d}$ after a chronic ethanol exposure regimen (Holmes et al., 
2012). Therefore, in contrast to the increase in NMDA receptor signaling associated with early withdrawal, prolonged withdrawal after chronic ethanol exposure may be associated with decreases in NMDA receptor activity and expression.

In vitro studies have shown previously that ethanol can disrupt different kinds of long-term plasticity (LTD and LTP) in the NAc (Jeanes et al., 2011; Mishra et al., 2012). Deficits in NAc shell LTD were also observed in rats after a chronic ethanol vapor inhalation regimen (Jeanes et al., 2011), and many studies have reported disruptions of accumbal synaptic plasticity after locomotor sensitization or self-administration protocols with psychostimulants (Thomas et al., 2001; Martin et al., 2006; Mao et al., 2009). For psychostimulants, there are significant differences in the impairment of accumbal synaptic plasticity when the recordings are made during early or protracted withdrawal or after an acute drug challenge (for review, see Madsen et al., 2012). In the present study, we have shown that after a protracted withdrawal, ethanolsensitized mice exhibited a significant impairment of NMDAdependent LTD expression in the NAc core, but not in the shell. Significant impairment of NAc core NMDA-dependent LTD was only observed in sensitized mice and not in ethanol-treated mice that failed to develop behavioral adaptation following chronic ethanol exposure. Individual differences in locomotor activity observed after a single ethanol treatment were not associated with any significant differences in LTD expression. Therefore, the impairment of LTD that we observed seems to be associated with the development of ethanol sensitization and not with any initial differences in locomotor responsivity to ethanol between sensitized and nonsensitized mice. Impairment of accumbal LTD may represent a form of neuroadaptation associated not only with the chronic effects of abused drugs, but also with a behavioral phenotype related to an increased vulnerability to addiction. Interestingly, this specificity has recently been demonstrated in a rodent model of cocaine addiction (Kasanetz et al., 2010). Although cocaine exposure initially disrupted LTD in the NAc core of all rats that self-administered cocaine, only animals that developed an addicted phenotype failed to recover the ability to express this form of synaptic plasticity (Kasanetz et al., 2010).

Low-frequency stimulation protocols can also induce NMDA receptor-independent forms of LTD, such as endocannabinoiddependent LTD in striatal neurons (Kombian and Malenka, 1994; Robbe et al., 2002). Indeed, we observed robust LTD in the NAc core in the presence of the NMDA receptor antagonist APV. However, under these recording conditions, no ethanol sensitization-associated impairment of LTD was observed. This finding, along with our other biochemical and electrophysiological data, supports our hypothesis that locomotor sensitization to ethanol is associated with a functional deficit in NAc core NMDA receptor function.

In summary, our data provide further evidence that the development of locomotor sensitization to ethanol may represent a behavioral correlate for increased vulnerability to alcohol addiction. Mice that developed this form of behavioral plasticity consumed more ethanol than did nonsensitized mice despite the fact that both groups received an identical ethanol treatment regimen before the voluntary drinking assay. Further, the development of ethanol locomotor sensitization was associated with a significant decrease in NAc NMDA receptor expression and function, as well as impaired NMDA receptor-mediated LTD, one form of synaptic plasticity that controls the balance of neuronal activity necessary to adapt behavior to an ever-changing environment. These synaptic alterations may contribute to the perseveration on the drug of abuse and the difficulty in learning new associations, which are key hallmarks of addiction. A better understanding of the molecular substrates responsible for this decrease in neuroplasticity could reveal new targets for the development of more effective therapies for drug and ethanol dependence.

\section{References}

Abrahao KP, Souza-Formigoni ML (2012) Behavioral sensitization to ethanol results in cross-sensitization to MK-801 but not to NMDA administered intra-accumbens. Behav Brain Res 235:218-224. CrossRef Medline

Abrahao KP, Quadros IM, Souza-Formigoni ML (2009) Individual differences to repeated ethanol administration may predict locomotor response to other drugs, and vice versa. Behav Brain Res 197:404-410. CrossRef Medline

Abrahao KP, Quadros IM, Souza-Formigoni ML (2011) Nucleus accumbens dopamine D1 receptors regulate the expression of ethanol-induced behavioural sensitization. Int J Neuropsychopharmacol 14:175-185. CrossRef Medline

Becker HC, Lopez MF (2004) Increased ethanol drinking after repeated chronic ethanol exposure and withdrawal experience in C57BL/6 mice. Alcohol Clin Exp Res 28:1829-1838. CrossRef Medline

Bell RL, Rodd ZA, Lumeng L, Murphy JM, McBride WJ (2006) The alcoholpreferring $\mathrm{P}$ rat and animal models of excessive alcohol drinking. Addict Biol 11:270-288. CrossRef Medline

Carrara-Nascimento PF, Olive MF, Camarini R (2012) Ethanol preexposure during adolescence or adulthood increases ethanol intake but ethanol-induced conditioned place preference is enhanced only when pre-exposure occurs in adolescence. Dev Psychobiol. Advance online publication. Retrieved Nov. 30, 2012. doi:10.1002/dev.21089. CrossRef

Crowder TL, Ariwodola OJ, Weiner JL (2002) Ethanol antagonizes kainate receptor-mediated inhibition of evoked GABA(A) IPSCs in the rat hippocampal CA1 region. J Pharmacol Exp Ther 303:937-944. CrossRef Medline

Deroche-Gamonet V, Belin D, Piazza PV (2004) Evidence for addiction-like behavior in the rat. Science 305:1014-1017. CrossRef Medline

Diaz MR, Christian DT, Anderson NJ, McCool BA (2011) Chronic ethanol and withdrawal differentially modulate lateral/basolateral amygdala paracapsular and local GABAergic synapses. J Pharmacol Exp Ther 337:162170. CrossRef Medline

Du X, Elberger AJ, Matthews DB, Hamre KM (2012) Heterozygous deletion of NR1 subunit of the NMDA receptor alters ethanol-related behaviors and regional expression of NR2 subunits in the brain. Neurotoxicol Teratol 34:177-186. CrossRef Medline

Fidler TL, Dion AM, Powers MS, Ramirez JJ, Mulgrew JA, Smitasin PJ, Crane AT, Cunningham CL (2011) Intragastric self-infusion of ethanol in high- and low-drinking mouse genotypes after passive ethanol exposure. Genes Brain Behav 10:264-275. CrossRef Medline

Finn DA, Snelling C, Fretwell AM, Tanchuck MA, Underwood L, Cole M, Crabbe JC, Roberts AJ (2007) Increased drinking during withdrawal from intermittent ethanol exposure is blocked by the CRF receptor antagonist D-Phe-CRF(12-41). Alcohol Clin Exp Res 31:939-949. CrossRef Medline

Grahame NJ, Rodd-Henricks K, Li TK, Lumeng L (2000) Ethanol locomotor sensitization, but not tolerance correlates with selection for alcohol preference in high- and low-alcohol preferring mice. Psychopharmacology (Berl) 151:252-260. CrossRef Medline

Grosshans DR, Clayton DA, Coultrap SJ, Browning MD (2002) Analysis of glutamate receptor surface expression in acute hippocampal slices. Sci STKE 2002:pl8. CrossRef Medline

Gulley JM, Hoover BR, Larson GA, Zahniser NR (2003) Individual differences in cocaine-induced locomotor activity in rats: behavioral characteristics, cocaine pharmacokinetics, and the dopamine transporter. Neuropsychopharmacology 28:2089-2101. CrossRef Medline

Holmes A, Fitzgerald PJ, MacPherson KP, DeBrouse L, Colacicco G, Flynn SM, Masneuf S, Pleil KE, Li C, Marcinkiewcz CA, Kash TL, Gunduz-Cinar O, Camp M (2012) Chronic alcohol remodels prefrontal neurons and disrupts NMDAR-mediated fear extinction encoding. Nat Neurosci 15: 1359-1361. CrossRef Medline

Hyman SE, Malenka RC, Nestler EJ (2006) Neural mechanisms of addiction: the role of reward-related learning and memory. Annu Rev Neurosci 29:565-598. CrossRef Medline

Ikemoto S (2010) Brain reward circuitry beyond the mesolimbic dopamine 
system: a neurobiological theory. Neurosci Biobehav Rev 35:129-150. CrossRef Medline

Jeanes ZM, Buske TR, Morrisett RA (2011) In vivo chronic intermittent ethanol exposure reverses the polarity of synaptic plasticity in the nucleus accumbens shell. J Pharmacol Exp Ther 336:155-164. CrossRef Medline

Kasanetz F, Deroche-Gamonet V, Berson N, Balado E, Lafourcade M, Manzoni O, Piazza PV (2010) Transition to addiction is associated with a persistent impairment in synaptic plasticity. Science 328:1709-1712. CrossRef Medline

Kombian SB, Malenka RC (1994) Simultaneous LTP of non-NMDA- and LTD of NMDA-receptor-mediated responses in the nucleus accumbens. Nature 368:242-246. CrossRef Medline

Krystal JH, Petrakis IL, Mason G, Trevisan L, D'Souza DC (2003) $\mathrm{N}$-methyl-D-aspartate glutamate receptors and alcoholism: reward, dependence, treatment, and vulnerability. Pharmacol Ther 99:79-94. CrossRef Medline

Lessov CN, Palmer AA, Quick EA, Phillips TJ (2001) Voluntary ethanol drinking in C57BL/6J and DBA/2J mice before and after sensitization to the locomotor stimulant effects of ethanol. Psychopharmacology (Berl) 155:91-99. CrossRef Medline

Lovinger DM, White G, Weight FF (1989) Ethanol inhibits NMDAactivated ion current in hippocampal neurons. Science 243:1721-1724. CrossRef Medline

Lüscher C, Malenka RC (2011) Drug-evoked synaptic plasticity in addiction: from molecular changes to circuit remodeling. Neuron 69:650-663. CrossRef Medline

Madsen HB, Brown RM, Lawrence AJ (2012) Neuroplasticity in addiction: cellular and transcriptional perspectives. Front Mol Neurosci 5:99. CrossRef Medline

Mameli M, Lüscher C (2011) Synaptic plasticity and addiction: Learning mechanisms gone awry. Neuropharmacology 61:1052-1059. CrossRef Medline

Mao LM, Wang W, Chu XP, Zhang GC, Liu XY, Yang YJ, Haines M, Papasian CJ, Fibuch EE, Buch S, Chen JG, Wang JQ (2009) Stability of surface NMDA receptors controls synaptic and behavioral adaptations to amphetamine. Nat Neurosci 12:602-610. CrossRef Medline

Martin M, Chen BT, Hopf FW, Bowers MS, Bonci A (2006) Cocaine selfadministration selectively abolishes LTD in the core of the nucleus accumbens. Nat Neurosci 9:868-869. CrossRef Medline

McCool BA (2011) Ethanol modulation of synaptic plasticity. Neuropharmacology 61:1097-1108. CrossRef Medline

Melón LC, Boehm SL 2nd (2011) Role of genotype in the development of locomotor sensitization to alcohol in adult and adolescent mice: comparison of the DBA/2J and C57BL/6J inbred mouse strains. Alcohol Clin Exp Res 35:1351-1360. CrossRef Medline

Mishra D, Zhang X, Chergui K (2012) Ethanol disrupts the mechanisms of induction of long-term potentiation in the mouse nucleus accumbens. Alcohol Clin Exp Res 36:2117-2125. CrossRef

Myme CI, Sugino K, Turrigiano GG, Nelson SB (2003) The NMDA-toAMPA ratio at synapses onto layer $2 / 3$ pyramidal neurons is conserved across prefrontal and visual cortices. J Neurophysiol 90:771-779. CrossRef Medline

Nagy J (2008) Alcohol related changes in regulation of NMDA receptor functions. Curr Neuropharmacol 6:39-54. CrossRef Medline

Newlin DB, Thomson JB (1999) Chronic tolerance and sensitization to alcohol in sons of alcoholics: II. Replication and reanalysis. Exp Clin Psychopharmacol 7:234-243. CrossRef Medline

Piazza PV, Le Moal ML (1996) Pathophysiological basis of vulnerability to drug abuse: role of an interaction between stress, glucocorticoids, and dopaminergic neurons. Annu Rev Pharmacol Toxicol 36:359-378. CrossRef Medline
Quadros IM, Hipólide DC, Frussa-Filho R, De Lucca EM, Nobrega JN, SouzaFormigoni ML (2002) Resistance to ethanol sensitization is associated with increased NMDA receptor binding in specific brain areas. Eur J Pharmacol 442:55-61. CrossRef Medline

Quadros IM, Nobrega JN, Hipolide DC, Souza-Formigoni ML (2005) Increased brain dopamine D4-like binding after chronic ethanol is not associated with behavioral sensitization in mice. Alcohol 37:99-104. CrossRef Medline

Rehm J, Mathers C, Popova S, Thavorncharoensap M, Teerawattananon Y, Patra J (2009) Global burden of disease and injury and economic cost attributable to alcohol use and alcohol-use disorders. Lancet 373: 2223-2233. CrossRef Medline

Robbe D, Kopf M, Remaury A, Bockaert J, Manzoni OJ (2002) Endogenous cannabinoids mediate long-term synaptic depression in the nucleus accumbens. Proc Natl Acad Sci U S A 99:8384-8388. CrossRef Medline

Robinson TE, Berridge KC (1993) The neural basis of drug craving: an incentive-sensitization theory of addiction. Brain Res Brain Res Rev 18: 247-291. CrossRef Medline

Sanchis-Segura C, Spanagel R (2006) Behavioural assessment of drug reinforcement and addictive features in rodents: an overview. Addict Biol 11:2-38. CrossRef Medline

Simson PE, Criswell HE, Johnson KB, Hicks RE, Breese GR (1991) Ethanol inhibits NMDA-evoked electrophysiological activity in vivo. J Pharmacol Exp Ther 257:225-231. Medline

Souza-Formigoni ML, De Lucca EM, Hipolide DC, Enns SC, Oliveira MG, Nobrega JN (1999) Sensitization to ethanol's stimulant effect is associated with region-specific increases in brain D2 receptor binding. Psychopharmacology (Berl) 146:262-267. CrossRef Medline

Spanagel R, Bartsch D, Brors B, Dahmen N, Deussing J, Eils R, Ende G, Gallinat J, Gebicke-Haerter P, Heinz A, Kiefer F, Jäger W, Mann K, Matthäus F, Nöthen M, Rietschel M, Sartorius A, Schütz G, Sommer WH, Sprengel R, et al. (2010) An integrated genome research network for studying the genetics of alcohol addiction. Addict Biol 15:369-379. CrossRef Medline

Steketee JD, Kalivas PW (2011) Drug wanting: behavioral sensitization and relapse to drug-seeking behavior. Pharmacol Rev 63:348-365. CrossRef Medline

Swendsen J, Le Moal M (2011) Individual vulnerability to addiction. Ann N Y Acad Sci 1216:73-85. CrossRef Medline

Thomas MJ, Malenka RC, Bonci A (2000) Modulation of long-term depression by dopamine in the mesolimbic system. J Neurosci 20:5581-5586. Medline

Thomas MJ, Beurrier C, Bonci A, Malenka RC (2001) Long-term depression in the nucleus accumbens: a neural correlate of behavioral sensitization to cocaine. Nat Neurosci 4:1217-1223. CrossRef Medline

Trujillo KA, Akil H (1995) Excitatory amino acids and drugs of abuse: a role for $\mathrm{N}$-methyl-D-aspartate receptors in drug tolerance, sensitization and physical dependence. Drug Alcohol Depend 38:139-154. CrossRef Medline

Vanderschuren LJ, Kalivas PW (2000) Alterations in dopaminergic and glutamatergic transmission in the induction and expression of behavioral sensitization: a critical review of preclinical studies. Psychopharmacology (Berl) 151:99-120. CrossRef Medline

Wang J, Lanfranco MF, Gibb SL, Yowell QV, Carnicella S, Ron D (2010) Long-lasting adaptations of the NR2B-containing NMDA receptors in the dorsomedial striatum play a crucial role in alcohol consumption and relapse. J Neurosci 30:10187-10198. CrossRef Medline

Zhou FC, Anthony B, Dunn KW, Lindquist WB, Xu ZC, Deng P (2007) Chronic alcohol drinking alters neuronal dendritic spines in the brain reward center nucleus accumbens. Brain Res 1134:148-161. CrossRef Medline 